\title{
AN ANALYSIS OF CODE SWITCHING AND FACTOR MOTIVATION IN NESSIE JUDGE VLOG
}

\author{
Dida Nurul Fadillah ${ }^{1}$, Aseptiana Parmawati ${ }^{2}$ \\ ${ }^{1}$ IKIP Siliwangi \\ ${ }^{2}$ IKIP Siliwangi \\ ${ }^{1}$ adidanurf05@gmail.com, ${ }^{2}$ aseptiana@ikipsiliwangi.ac.id
}

\begin{abstract}
The phenomena of language is a phenomena that is currently happening in Indonesia as well as the language and style of language in communication, mix or switch into another language especially English and it can be called Code Switching. Many sources of media that we can use to see how code switching is, and one of the flatfrom is Vlog. Based on the introduction, this research tries to analyze a code switching, the main is the types, and analyze a factor motivation by using descriptive qulitative method. The aims of this article are to find out the types of code switching from Nessie utterances in her vlog using code switching and the factor motivation that influenced in doing code switching. Based on the finding of data that the writer analyze from Nessie Judge's utterance in her vlog, the most types of code switching that in Nessie Judge utterances is Intersentential type.
\end{abstract}

Keywords: Language Phenomena, Factor Motivation, Code Switching, Vlog

\section{INTRODUCTION}

In this century, the $21^{\text {st }}$ century, there are many phenomenon in social life, especially in language. The youths are often up to date about what happened in their environment, either fashion or technology. They always follow the trend that existed at that moment. We even hear Indonesian youths, especially those living in cities, switching and mixing between English and Indonesian in their discourses. Many reasons why we do code switching, such as Attitude type, that is the type caused by their background, whereas Linguistic type, that is the type caused by our ability in language. Language is needed to be understood what the goals it is going to be and to convey ideas and information through oral or written. language itself is able to be learnt and studied by brace of science, it is called linguistic (Aprianti and Parmawati, 2020). In Indonesia, we can guess from Attitude type, that may be rarely for people do code switching because their background, perhaps only certain people who can do it without need to learn first. Code switching is a part of Pragmatic. pragmatics is the study of language from a functional perspective, that is attempts to explain facets of linguistic structure by reference to nonlinguistic pressures and causes (Levinson, 1983 cited in Kuswandi \& Apsari, 2019).

Code switching is a change by a speaker or writer from one language to another in the middle of their discourse or sometimes even in the middle when producing sentences. This phenomenon does not only occur in daily communication in real life, but can also be found in various parts of the media which represent and reflect real-life situations such as literature, movies, songs and Youtube. Youtube is one of platform for people to watch or share about anything, such as music video, TV Program, lesson, recipe, tutorial etc. Most of teens in Indonesia, especially, using Youtube for learning, watching the knowledge that never been give from school, and many more. 
Now, the famous phenomenon in Youtube that is Vlog.Vlog is a blog that contains video content. In Indonesia, there are many famous vlogger, such as Sara Wijayanto, Filo Sebastian, Dedi Corbuzier, Boy William, and Nessie Judge. Nessie Judge is One of Vlogger in Youtube who is known for her eponymous channel's content, that is Nerror (Nessie Horror). At the beginning, her content was a vlog contains her daily life in Europe, interspersed with content about Indonesia such as interviewing foreigners wheter they re know about Indonesia or not. Time by time, the video content has developed, and in mid of 2017, Nessie introduced new content that is NERROR (Nessie Horror) which contains horror content, mysteries, and conspiracy theories, such as the conspiracy of Google Translate, the scariest artist conspiracy, the conspiracy of Lady Diana accident, the case of Mysterious Murder | Jon Benet Ramsey and many more. In her video, she is often use many code switching and code mixing in her utterances. She combines the Indonesian and English language when lead her vlog.

In this case, The writers choose this topic due to the writer interest in use of code switching, also want to analyze the code switching and the type of code switching that is used in her video. The aim of the research is to find the types of code switching from her utterances in using codeswitching and the factor motivation that influeced in doing code switching. Also expected to provide information needed by the reader in studying code-mixing and code-switching, so the reader would get more understanding about types of code-switching and the factor motivation that influenced in vlog..

\section{METHOD}

The writers used a descriptive qualitative method. According to (Tavakoli, 2012), "Descriptive research is similar to qualitative research because that is deal with naturally occuring phenomena, using data which may either be collected first hand or taken from already existing data sources as data from other studies, student records, and so on, without intervention of an experiment or an artifically contrived treatment." The writers want from this research are to tell what the social factor motivation that influenced the Object, and make a category of each types of code switching on table of the sentences that contain with code switching that found in the Object utterances.

In this research, the writer took the object of this research is Nessie Judge, is one of them, that used code switching on their utterances in their vlog. There are some steps of research that the writer do. First, all sources of the data that exist for analyzing her that used in this research, the writer took it from Nessie Judge channel on YouTube, and the writer watch three of Nessie Judge's Vlog until end as sample of data.

Second, the writer analyze what the types of code switching that she used in her vlog, analyze the factor motivation that influenced Nessie Judge in doing code switching based on her profile. According to (Holmes, 2017), "Social aspects like the context, participant, the topic and purposes are important factors in explaining various sociolinguistic phenomenon such as borrowing, diglossia, code switching, register, style, and interference". Last step, the writers make a conclusion based on finding and discussion of analyzing all of the data that used in this research. 


\section{RESULTS AND DISCUSSION}

Results

Table 1.

The $1^{\text {st }}$ Vlog : KONSPIRASI kecelakaan PUTRI DIANA! - \#NERROR

\begin{tabular}{|c|c|c|}
\hline No. & Utterance & Types of Code Switching \\
\hline 1. & First of all, Satu juta subscriber. & Intrasentential \\
\hline 2. & $\begin{array}{l}\text { Mayoritas orang percaya akan konspirasi-konspirasi } \\
\text { kematian Lady Diana, Putri Diana Spencer. }\end{array}$ & Tag Switching \\
\hline 3. & Stop senyum-senyum! Cause shit's about to go down! & Intersentential \\
\hline 4. & $\begin{array}{l}\text {... dan pernikahannya disebut sebagai "fairytale } \\
\text { wedding". }\end{array}$ & Intersentential \\
\hline 5. & $\begin{array}{l}\text { Jadi, basiclly, pernikahannya ancur gitu kaya, Charl } \\
\text { selingkuh, Diana tau Charl selingkuh, terus dia selingkuh } \\
\text { juga. }\end{array}$ & Intrasentential \\
\hline 6. & $\begin{array}{l}\text { So, here's the thing. Putusan itu menuai banyak banget } \\
\text { tanda tanya dan konspirasi. That's why we here, cause } \\
\text { you guys request this. }\end{array}$ & Intersentential \\
\hline 7. & $\begin{array}{l}\text { Semua konspirasi yang dipercaya sama semua orang, } \\
\text { mayoritas, at least, bahwa Putri Diana dibunuh dan } \\
\text { kecelakan direncanakan oleh Royal Family. }\end{array}$ & - \\
\hline 8. & $\begin{array}{l}\text { And if You guys who living in the bubble, kalau kalian } \\
\text { tinggal di dalam gelembung mindset yang berfikir } \\
\text { bahwa..... }\end{array}$ & Intersentential \\
\hline 9. & $\begin{array}{l}\text { Masih bisa dilihat, Dia masih tegap, gak goyah, kelihatan } \\
\text { sangat-sangat sober, jadi banyak orang yang percaya } \\
\text { bahwa mungkin dia di kambing hitamkan saja. }\end{array}$ & - \\
\hline 10. & $\begin{array}{l}\text { So, I wanna know what do you think. Aku mau tau } \\
\text { menurut kalian, apa yang terjadi sama Putri Diana. }\end{array}$ & Intersentential \\
\hline
\end{tabular}

Table 2.

$2^{\text {nd }}$ Vlog : KONSPIRASI artis TERSERAM- Michael Jackson! - \#NERROR

\begin{tabular}{lll} 
No. & \multicolumn{1}{c}{ Utterance } & $\begin{array}{c}\text { Types of Code } \\
\text { Switching }\end{array}$ \\
\hline 1. & $\begin{array}{l}\text { Topik yang paling, paling, paling, paling bayak di request, dan } \\
\text { topik yang paling, paling, paling lama di riset. So, I just } \\
\text { wanna show you guys. }\end{array}$ & Intersentential \\
\hline 2. & $\begin{array}{l}\text { Riset yang paling lama yang pernah aku lakukan untuk video. } \\
\text { But you guys wanna it so much. So here we are. }\end{array}$ & Intersentential \\
\hline 3. & Tanpa bertele-tele lagi. So, with that any for there to do. & Intersentential \\
\hline 4. & $\begin{array}{l}\text { Hariini, Kita akan ngomongin Michael Jackson, The King of } \\
\text { Pop. }\end{array}$ & Tag Switching \\
\hline
\end{tabular}


5. Satu dunia shock, berita nya ada dimana-mana, banyak fans nya yang berduka, dan lagunya di putar disemua toko yang

Tag Switching aku datengin hari itu. It was crazy.

6. Banyak orang yang bingung dan penasaran, dan ini juga Intersentential kayanya yang memulai banyak konspirasi, karena petinya Michael Jackson tertutup. Itu bukanlah sebuah hal normal pada pemakaman but I don't know.

7. Rekaman CCTV rumah Michael Jackson, selama 24 jam sebelum kematiannya misterius hilang tanpa alasan. You can not find it.

8. Ada seorang anak kecil yang melewati Bungalo itu dan bersumpah, bahwa dia mendengar suaranya Michael Jackson. Karena suaranya sangat-sangat distinctive ya. Unik banget, dan sangat-sangat berbeda.

9. Dengan semua konspirasi teori, kita masih harus menghormati, kalau misalnya Michael Jackson memalsukan kematiannya, kita harus hormati keputusannya, thats on him.

10. Dan kita harus lebih menghormati lagi fakta yang diumumkan bahwa dia meninggal pada 25 juni 2009, may he rest and Intersentential peace.

Table 3.

$3^{\text {rd }}$ Vlog : BONEKA2 yg terekam kamera BERGERAK SENDIRI!

No. Utterance Types of Code Switching

1. Waku aku kecil sebagai cewe, as normaly, aku punya banyak banget boneka.

2. Jadi di video ini,mereka lagi main Ouija board dan ternyata katanya boneka yang ada dibelakangnya itu bergerak sendiri, so we gonna watch it.

3. I don't know how to say, kek aku kira tadi pertamanya pake string, setelah dia balik lagi main itu kaya bonekanya geraknya udah bukan kaya pake string lagi, udah kaya bener-bener...

4. Arwah anak kecil itu sekarang menempati boneka kesayangannya. It's like sad.

5. Guys, it seriously. Aku punya barbie doll, dan aku tahu Intersentential bahwa kepalanya gak bisa secepet itu.

6. I don't know think that its possible to do that, kasian Intersentential banget anak kecilnya.

7. Kalau aku jadi James, aku udah gasuka lagi sama Elmo. Tag Switching That's ..... a scariest hell.

8. Yang ini judulnya, creepy dolls move. so lets do it. Intersentential

9. Ya ampun ngapain sih, koleksi tuh boneka serem banget, Tag Switching this is like a scariest hell. 
10. I wanna stop watching this, cause that's what. Siapa

Intersentential punya satu ruangan yang isinya boneka.

\section{Discussion}

Based on the finding of data from Nessie Judge's utterance in her vlog, the writers found code switching and also the types of Nessie Judge Vlog. There are 3 criterias such as Intersentential, Intrasentential, and Tag Switching. According to Mahootian S (2006:46) cited in Nalendra et al., (2017), "The classification of code switching divided in three criterias, are Intersentential switching is a change in one language occurs at a clause or sentence boundary, Intra-Sentential is switches occur within a clause or sentence boundary and Tag Switching is tags and certain set phrases in one language are inserted into an utterance otherwise in another."

Through the data that the writers found in first vlog, the most type of code switching in Table 1 is Intersentential has 5, Tag switching has 1 and Intrasentential has 2 . In second vlog, the most type of code switching in the Table 2 is Intersentential has 6, tag switching has 3 and Intrasentential has 0 . And the last, In third vlog, the most type of code switching in the Table 3 is Intersentential has 6, tag switching has 3 and Intrasentential has 0.

Based on the analyze and observe the data. Nasreen Anisputri Judge or Nessie Judge was born in Solo on October 30, 1993. Her father is Indonesian (Pakistan and Tionghoa descent), while her mother is Indonesian (Netherland and Pakistan descent). Her parent never speak English in home, although her father can speak English. She fluent in speak English, because of she attended international school since middle school because every student speak English, all materials using English, even in outclass the student speak English, lived in Finland for a few months, and she took her study in aboard, also in her first time to learn English, she often practice talk to herself in everytime, of course, set a goals what did she want to get it.

Many reason why people do code switching, such as Attitude type, that is the type caused by their background, whereas Linguistic type, that is the type caused by our ability in language. The dominant factor in code switching is social aspects.

Based on the writer's understanding and opinion, the factor motivating that influenced for Nessie Judge do a code switching in her vlog on her daily communication because of social and lingustic factors or types. It means that Nessie Judge always do a code switching in her utterance on Vlog because of her ability in language, her habitual in which usually speak with each other in her community as billingualism, the function of the language in use, to make the audience have a better understanding of utterance in her vlog, such as expression etc.

\section{CONCLUSION}

Code switching has many types such as Intersentential, Intrasentential, and Tag Switching. Based on the finding of data that the writer analyze from Nessie Judge's utterance in her vlog, the most types of code switching that in Nessie Judge utterances is Intersentential type.

Based on the writer's understanding and opinion, the factor motivating that influenced for Nessie Judge do a code switching in her vlog on her daily communication because of social and lingustic factors or types. It means that Nessie Judge always do a code switching in her utterance on Vlog because of her ability in language, her habitual in which usually speak with each other 
in her community as billingualism, the function of the language in use, to make the audience have a better understanding of utterance in her vlog, such as expression etc.

\section{ACKNOWLEDGMENTS}

The writer want to say thank you so much, for the many sources and lecturers, also thank you so much to Mrs. Aseptiana Parmawati who have given guide and support for me to complete this article, so the writer can publish the article as partial fulfillment of the requirements for the attainment of the Sarjana Pendidikan Degree in the English Language Education.

\section{REFERENCES}

Aprianti, I. N., \& Parmawati, A. (2020). Derivational And Inflectional Morpheme Analysis On The Song Lyrics Of Lady Gaga “A Star Is Born” Album. Project (Professional Journal Of English Education), 3(3), 322-328.

Geman, C. (2016). A Study Of Code Switching In The Movie I Not Stupid Too. International Journal Of Applied Linguistics And Translation, 2(6), 53.

Holmes, J. \&. (2017). An Introduction To Sociolinguistics. Routledge.

Inuwa, Y. N., Christopher, A. A., \& Bakrin, H. B. (2014). Factors Motivating Code Switching Within The Social Contact Of Hausa Bilinguals. Iosr Journal Of Humanities And Social Science (Iosr-Jhss) Volume, 19, 43-49.

Khoirunada, M. Code-Switching And Code Mixing In Tv Talk Show At Net Tv. Progressive, 12(2), 31-36.

Kuswandi, M., \& Apsari, Y. (2019). An Analysis Of Pauses, Overlaps And Backchannels In Conversation In Vlog By Nessie Judge. Project (Professional Journal Of English Education), 2(3), 282-291.

Nalendra, A. R. (2017). Code-Switching And Code Mixing In Tv Talk Show At Net Tv. Progressive Journal, 12(2), , 95-100.

Suprijadi, D., \& Kaswan. (2011). A Brief Introduction To Language In Society. Bandung

Tavakoli, H. (2012). Dalam A Dictionary Of Research Methodology And Statistics In Applied Linguistics (Hal. 60). Rahnama Press.

Wardhaugh, R. (2011). Dalam An Introduction To Sociolinguistics (Vol. 28). John Wiley \& Sons. 